\title{
Researches on the Vitality and Self-digestion of the Endosperm of some Graminaceae. ${ }^{1}$
}

\author{
BY
}

DIANA BRUSCHI, D.SC.

\section{Argument and Literature.}

TWO different methods have been followed in order to solve the 1 question whether the reserve material contained in the endosperm of amyliferous seeds is exclusively digested by enzymes secreted during germination, or whether the endosperm cells renew their vital activity and themselves dissolve their own food material. The first method consisted in seeking whether the embryo really secretes enzymes; the second in testing whether the embryo can develop and live if removed from the endosperm and provided with food artificially.

Van Tieghem ('73) and Blociszewski ('76) found that several embryos isolated from their endosperm developed when placed on starch jelly, but they took no account of the bacteria which had no doubt infected their cultures and had dissolved the starch by means of their powerful diastase. The same objection applies to the researches of Brown and Morris ('90), and Grüss ('94), according to whom the isolated embryo of Barley develops on, and liquefies, starch jelly.

Linz ('96) succeeded in making sterile embryos of Maize grown on a jelly containing soluble starch, and he found that by means of the scutellum they absorbed and secreted sugar, but did not liberate the slightest trace of diastase. Grüss confirmed this in a later paper ('97).

The epithelium of the scutellum, then, is not a diastase-secreting gland, although its cells grow enormously in length during the endosperm evacuation, and they show all the characters of vigorously secreting cells, as the cytological researches of Reed ('04), Sargant and Robertson ('05) have demonstrated. This last fact can be explained even if these cells do not liberate enzymes, for, as Linz has shown ('96), they produce most of the amylase for the nutrition of the embryo, and absorb and elaborate,

1 From the Physiological Laboratory of the University Botanic Garden, Rome (I905-I906). (This paper is an abstract of several preceding papers, quoted at the end.)

[Annals of Botany, Vol. XXII. No. L,XXXVII. Ju1y, 1908.] 
as Brown and Morris have already proved, all the digestion products of the endosperm.

If the embryo does not furnish diastase to the endosperm, one must needs think that the latter dissolves its own contents. This brings us to a series of researches which I intend to complete and enlarge with my own work.

Sachs ('62) held that the endosperm of Gramineae remained quite passive during germination, and was actively exhausted by the embryo.

Gris ('65) had noted the different behaviour of amylaceous endosperms compared with those containing aleurone or oil as reserve material.

The first experiments were made by Van Tieghem ('77), who found that isolated endosperms of Ricinus communis, placed under conditions comparable to germination, respired and digested themselves till the aleurone and oil were consumed, while the starchy endosperm of Canna, and the horny endosperm of Date ${ }^{1}$ remained passive and unchanged. This indicated that endosperms containing aleurone and oil digest themselves, and hence are living, while amylaceous endosperms and those containing hemicellulose as reserve material cannot digest themselves and so do not possess vitality.

Brown and Morris, after an extended study on the endosperm of Barley, agreed with Van Tieghem that the endosperm of Gramineae is a 'dead magazine' of reserve material. Ultimately they found that the diastatic capacity of the scutellum cells is destroyed by treatment with chloroform vapour.

They say that the endosperm cells are dead, although they contain diastase, since they later become dissolved. Certainly, Brown and Morris experimented exclusively with Barley in which, long before the starch is liquefied, the walls of the endosperm cells are totally destroyed, so that one could hardly designate such cells as living ; nevertheless, in Maize grains the scutellum does not emit diastase, ${ }^{2}$ - so, in this plant at least, the endosperm cells must produce it on their own account. Here is already a difference between Maize and Barley.

Haberlandt ('90) maintained that the aleurone layer alone secretes the whole of the diastase which dissolves the endosperm reserves, based on the fact that starch grains are attacked within twenty-four hours when placed on the isolated and washed aleurone layer. He prevented the advent of any amylase from the scutellum by interrupting the communication between this organ and the aleurone layer by means of a circular incision. But these experiments prove only that the aleurone layer also contains diastase. In fact, Linz has demonstrated that diastase occurs in the aleurone layer of Maize, which increases during germination as it is

${ }^{1}$ For 'digestion of Dates,' see Vinson ('07).

2 The contrary affirmations of Laurent ('00) seem to deserve confirmation. 
increasing in the endosperm; but the quantity of ferment produced by the scutellum is always much larger.

With great skill Pfeffer ('93) and his scholar Hansteen ('94) approached the subject. They did not exactly accept Van Tieghem's statements as to autonomous evacuation occurring only in oleaceous seeds and not at all in amylaceous ones. Van Tieghem had not provided for the elimination of the products of digestion, the accumulation of which would entirely prevent further digestion, as might be easily foreseen, by the principle of mass-action which governs all reactions in chemical equilibrium.

In so far as reversible reactions are concerned, as soon as the products of decomposition have reached a certain concentration the velocity of reaction in the sense of decomposition tends to become zero, while the inverse reaction, the reconstitution of starch, becomes perceptible.

By Pfeffer's advice, Hansteen, in order to obtain the rapid removal of the starch dissolution products, fixed isolated endosperms on small plaster columns immersed almost to the top in a sufficient quantity of water. The endosperms were well aerated, and the starch dissolution products, issuing from the endosperm from the wounded side (whence the embryo had been cut off), diffused through the plaster into the surrounding liquid. In this manner a complete evacuation was secured, with removal of the reducing sugar from the starchy endosperms of Barley, Wheat, and Rye; the process was almost complete in Maize, in the horny endosperm of Date (hemicellulose), and in other reserve tissues. If the quantity of water was limited, the evacuation was arrested almost as soon as it began.

From these results Hansteen concluded that even mealy and horny endosperms are alive, only a necessary condition for their emptying is the continuous export of the products of dissolution.

Grüss also observed ('95) that the products of the diastatic decomposition of starch paralyse the amylase action.

Linz ('96) repeated these experiments with Maize endosperms, putting them into a moist space, but so that nothing could be sent off, and he found an increase of diastase. ${ }^{1}$ The same result was obtained by keeping endosperms for five days on damp blotting-paper.

Grüss ('96) found that sterile endosperms of Maize, kept for twelve days under conditions comparable to germination, gave a very positive reaction with hydrogen peroxide and guajacum. He obtained a similar result with Barley endosperms. If the guajacum test was available for demonstrating diastase, it could be argued that Maize and Barley endosperms form enzymes independently from the embryo. But the guajacum test is only workable for the oxidase, whose presence is known in the flour as well, that is, in evidently dead endosperm material.

By placing endosperms on little plaster columns in 8 o c.c. water, Linz

${ }^{1}$ Brown and Morris had found that, under such conditions, diastase does not increase. 
could not observe any corrosion of the starch grains at first. He also stated that diastase does not diffuse in the liquid, but that it continues to increase slowly up to the eighteenth day, so that, at the end, the starch grains are partially corroded and dissolved. The corrosion begins about the eighth day and increases till the eighteenth, as happens in normal germination. The increase of diastase in the isolated endosperm may be regarded as a proof of the vitality of this tissue stronger than that afforded by Hansteen's experiments, because, as Linz observes, even if the question were one of dead amylases, one would still have the phenomena on which Pfeffer insists. Haberlandt had previously remarked the importance of removing the products of amylosis, because he had noticed that if the embryo of Rye was cut off right to the scutellum no evacuation occurred, while it did happen if a stump of growing root was left. Under similar conditions Haberlandt only obtained an incipient dissolution in Maize, and he explained it by admitting that, in spite of the supposed secretion of diastase by the nitrogenous layer, the isolated endosperms did not empty themselves in his experiments.

Linz objects that it is not true, as Haberlandt states, that the dissolution begins from the periphery in all reserve organs, and he observes that the detached aleurone layer corrodes starch because it contains broken cells which allow diastase to diffuse out. Hansteen had, in the meantime, found that endosperms deprived of the aleurone layer and fixed on plaster, dissolve their starch. So, as Linz observes, one could believe that amylase had already migrated from the aleurone layer, had Linz himself not shown that diastase also increases in the isolated endosperm.

When Grüss, in a series of papers ('93, '94, '95, '96), attempted to support Haberlandt's views, and rather brought confusion than light into this intricate question, Puriewitsch ('98) by Pfeffer's advice, repeated Hansteen's experiments on Wheat, Rye, Barley, Rice, Tetragonolobus purpureus, Phoenix dactylifera. He put them upon little plaster columns immersed in 200 c.c. water, with the addition generally of a cubic centimetre of 5 per cent. solution of phosphoric acid, or in a solution of .5 per cent. $\mathrm{KH}_{2} \mathrm{PO}_{4}$. Thence followed a notable corrosion of the starch grains, and the reducing substances diffused in the external liquid. The experiment was carried on for several days at $25^{\circ}-27^{\circ} \mathrm{C}$. The starch corrosion began near the scutellum and proceeded towards the middle of the endosperm. According to Puriewitsch the temperature hastens the evacuation because it increases respiration and accelerates the action of the diastase. Also he noticed that an accumulation of digestion products prevents the final emptying; hence he generally used a considerable quantity of water. In the outside liquid reducing substances were found, which increased when the liquid was boiled with dilute sulphuric acid. The quantity of nonreducing sugar gradually lessened as evacuation went on; hence he thinks 
an easily soluble sugar, already formed, at first comes out from the endosperm, and afterwards the sugars formed by the decomposition of starch.

Sugars, and salts like $\mathrm{KNO}_{3}, \mathrm{CaCl}_{2}$, and $\mathrm{KCl}$, at higher concentration than 5 per cent., stopped the evacuation in Puriewitsch's experiments. He explains this arrest by assuming a partial plasmolysis, which impedes the exosmosis of substances from the cell, a view which conflicts with several experiments made with yeast, in which plasmolysed cells even secrete invertase. $^{1}$

Besides, Grüss had already made use of plasmolysis in order to cause exosmosis of diastase from germinating seeds. Also Puriewitsch has not taken into account that certain other salts, especially calcium phosphate, and even plaster itself, accelerate the activity of amylase.

The chief argument for vitality brought forward by Puriewitsch is the action of narcotics. According to our author, chloroform and ether prevent the evacuation of Maize endosperms. Of less value for the demonstration of the vitality of the endosperm cells is the observation of Puriewitsch that endosperms which are not well aerated do not empty. Indeed, if by chance we find amylase in the resting seed, chiefly in the form of proenzymes which become active by oxidation during germination, we have a similar result. On the latter point one remembers that some years ago Baranetzky ('78), Wortmann ('82), and Detmer ('83) proved that free oxygen is necessary for the formation of diastase in seeds. In short, the very experiment which ought to be the most convincing yields to Puriewitsch a result contrary to his views. Various living reserve organs after artificial evacuation fill up again if placed in concentrated nutritive solutions; but with starch and horny endosperms this did not succeed. Notwithstanding this, Puriewitsch and Pfeffer ('97) maintain that amylaceous and horny endosperms are alive, and that their evacuation is a purely vital process.

Brown and Escombe ('98, p. I4) have confirmed the fact that Barley endosperms soaked in chloroform water for twenty-four hours did not show any solution for several days, at the end of which time they were invaded by moulds and bacteria, while non-chloroformed endosperms showed a considerable evacuation. The authors observe that in this case the solution was sub-aleuronic, and they endeavour to demonstrate that only the aleurone cells can be alive.

Moreover, the cytological study of the endosperm cells indicates to these authors that, while the cells of the aleurone layer have a well-defined nucleus and all the usual marks of living cells, the starch-containing cells of the endosperm have deformed nuclei and a structure like that of aged cells. Brown and Escombe also deny the auto-digestive capacity of the amyliferous cells, because Barley endosperm, deprived of embryo and aleurone layer, and kept under conditions favourable for germination and for the removal of the 
products of starch dissolution, did not show any difference when compared with chloroformed endosperms. Hence they concluded that although the peripheral layer of the endosperm, the so-called aleurone layer, without doubt consists of living cells, proof could not be obtained of the existence of vitality in the starchy cells which constitute the greater part of the endosperm. However, they admit that the isolated endosperm of several Gramineae and of the Date is capable of emptying itself, provided a continuous removal of the decomposition products is assured. But this fact, in Brown and Escombe's estimation, does not suffice to show that a tissue is alive.

Recently Pound ('06, p. I8I) found that the isolated endosperm does not dissolve itself, contrary to the affirmations of Hansteen and Puriewitsch.

My own researches have for a starting-point Puriewitsch's experiments, which I have carefully repeated. But I have not rested content with his methods and arguments, but have used various methods to ascertain if there is vitality, and if so how much vitality, in the endosperm of the four principal grains-Maize, Wheat, Barley, and Rye.

I began by studying the endosperm evacuation in the entire germinating seed, in order to compare it with the artificial emptying of isolated endosperms.

In the latter case the seeds, after being soaked for forty-eight hours in fresh water, were disinfected externally in 3 per cent. copper sulphate ; then, after being deprived of the embryo and scutellum, they were put in Koch's boxes on little plaster columns or platforms, which were sterilized and plunged into sterile tap or distilled water or in $1 \frac{1}{10} \overline{0}$ phosphoric acid.

The experiments were made both in free air and in chloroform atmosphere. After every experiment, portions of the material were fixed in different fixing media.

\section{MAIZE.}

The endosperm of Maize, in addition to the aleurone layer, shows a peripheral portion rich in protoplasm with the consistency and aspect of a horny tissue (glutinous portion) and a central part poor in protoplasm and of mealy consistency (farinaceous portion). In the isolated endosperms complete evacuation never occurs, but only a total destruction of the farinaceous portion and of a part of the glutinous mass, with very strong corrosion of the starch grains and diffusion of reducing sugar and other products of digestion (albumins) in the surrounding liquid.

The varieties of Maize used in these experiments were :-Zea Mais, var. romana, Quarantino Mais, Zea Mais saccharata lilacina dulcis, Zea Mais saccharata rubra dulcis.

Quarantino Mais gave the best results. 
The greatest evacuation occurred about the 16 th-I 8 th day, as in the normal germination of the whole seed. Chloroform does not entirely stop, but greatly retards, the self-emptying of the endosperm.

Having obtained the latter result, one wished to see if amylase could, at the expense of a pre-existing zymogen, increase in the endosperm cells even when every trace of vitality in these was utterly destroyed, which would give rise to similar results to those spoken of above.

I give some experiments in full :-

I. 100 seeds of Mais quarantino (dry weight $30.5 \mathrm{gm}$.) after forty-eight hours' soaking were deprived of scutella and embryos, and were then well pounded and mixed with 100 c.c. 20 per cent. glycerine and some chloroform. Juice A.

The scutella and embryos were pounded separately with similar additions of glycerine and chloroform. Juice B.

The juices were left to digest at $\mathrm{I} 8^{\circ} \mathrm{C}$. in darkness. From time to time the reducing sugar and amylase were determined, the latter by treating for one hour at $56^{\circ}$ C. IO c.c. of juice with Io c.c. 2 per cent. soluble starch - prepared after Lintner's method ('86)-with the addition of I c.c. of $\frac{11}{1} \frac{1}{0}$ hydrochloric acid.

\begin{tabular}{|c|c|c|c|c|}
\hline \multirow{2}{*}{ Date. } & \multicolumn{2}{|c|}{ A. } & \multicolumn{2}{|c|}{$B$. } \\
\hline & Sugar in 5 c.c. & Amylase of 5 c.c. & Sugar in 5 c.c. & Amylase of 5 c.c. \\
\hline $\begin{array}{cc}\text { April } & \mathbf{I} \\
\Rightarrow & \mathbf{I} 7 \\
, & \mathbf{3 0}\end{array}$ & $\begin{array}{c}\mathrm{CuO} \mathrm{mg} . \\
\mathrm{I} 7 \\
67 \\
30\end{array}$ & $\begin{array}{c}\mathrm{CuO} \mathrm{mg.} \\
\text { traces } \\
2-3 \\
2 \mathrm{I} 9\end{array}$ & $\begin{array}{c}\mathrm{CuO} \text { mg. } \\
72 \\
130 \\
43^{2}\end{array}$ & $\begin{array}{c}\mathrm{CuO} \mathrm{mg} . \\
42 \cdot 5 \\
51 \cdot 0 \\
684.0\end{array}$ \\
\hline
\end{tabular}

II. Ioo seeds of Quarantino Mais (dry weight $29.28 \mathrm{gm}$.) were deprived of the scutella and embryos after forty-eight hours' soaking. The endosperms were well pounded with the addition of 25 c.c. glycerine, and 2.5 c.c. chloroform water. Juice A.

The scutella and embryos were treated separately in the same way. Juice B. Digestion at $20^{\circ}-25^{\circ} \mathrm{C}$.

\begin{tabular}{|c|c|c|c|c|}
\hline \multirow{2}{*}{ Date. } & \multicolumn{2}{|c|}{ A. } & \multicolumn{2}{|c|}{$B$. } \\
\hline & Sugar in 5 c.c. & Amylase of 5 c.c. & Sugar in 5 c.c. & Amylase of $5 \mathrm{c.c}$ \\
\hline $\begin{array}{cc}\text { May } & 4 \\
\text { J II } & \text { II }\end{array}$ & $\begin{array}{l}\mathrm{CuO} \mathrm{mg} . \\
\text { trace } \\
\text { I } 84 \\
\text { I } 16.96\end{array}$ & $\begin{array}{c}\mathrm{CuO} \mathbf{m g} . \\
20 \\
98.8 \\
\mathbf{1} 8 \mathbf{2 . 8}\end{array}$ & $\begin{array}{c}\mathrm{CuO} \mathrm{mg} . \\
\text { trace } \\
\text { I I } 3.5^{2} \\
89.44\end{array}$ & $\begin{array}{c}\mathrm{CuO} \mathrm{mg} . \\
9 \\
\mathrm{I} 4 \mathrm{I} \cdot 9 \\
\mathrm{I} 9.68\end{array}$ \\
\hline
\end{tabular}

Thus one sees there was a constant increase of sugar and amylase in all juices; only during the first day was the synthetic power of the enzyme predominant. Indeed, reducing sugars were not found in the 
hydrolytic test, and preformed sugars almost disappeared - a new and important fact to which I shall return in another paper. The synthetic action of the amylase of Maize is greater for the enzyme of the endosperm than for that of the embryo, in which it may be entirely lacking (Exp. II); it exists only in the early days of evacuation, and afterwards it is overwhelmed by a powerful hydrolytic action which steadily increases. One can therefore maintain that amylase exists in the endosperm as a proenzyme or zymogen which becomes active during germination, possibly owing to contact with the air or through the action of cellular acids. It is to be noted that Reychler ('89), and Lintner and Eckhardt ('90) had observed after treating the gluten of Gramineae with dilute acid that it acquires a weak diastatic power; it is evident that this gluten held fast a small quantity of pro-amylase.

So we can no longer hold the view that the increase of diastase in the isolated endosperm constitutes a proof of the vitality of its cells, and one must turn to various methods of cell physiology.

At first, use was made of the plasmolys method, which gave very uncertain results, because the abundance of reserve material accumulated in the cells prevented accurate observation; but a trace of plasmolysis seemed to occur in the cells of the horny portion of the endosperm. On the contrary, by using the method of 'vital staining' (staining of living tissues) with methyl violet or aniline blue, one obtained a deep coloration of the whole farinaceous part and of some of the cells of the horny layer which lay most distant from the aleurone layer, while most of the cells of the horny portion, especially near the aleurone cells, did not take the stain ; the gradual passage from the living cells occurring at the periphery of the endosperm to the dead cells in the middle was very instructive.

Nuclear staining was attempted by different methods. Those lying near the aleurone layer stain easily with iodine green, methyl green, and eosin; they are less deformed and smaller, while the deformation and resistance to the stain increased in the farinaceous portion. So we cannot say that the nuclei are totally dead, but it is proved as a matter of fact that they will absorb none of those stains which are rapidly taken up by young and living cells. The nucleus is frayed and vacuolated, and shows increasing decrepitude from the periphery to the middle of the endosperm.

\section{BARLEY.}

All the above experiments were carried out with Barley (Hordeum distichum), and show that in the Barley endosperm evacuation, if not complete, is much greater than in Maize. $\frac{11}{10}-$ phosphoric acid again facilitates the endosperm emptying, while chloroform has a much less deterrent action than upon the Maize endosperm. These facts all indicate that the vitality of the Barley endosperm must be less than that of Maize. 
It is to be remarked that Puriewitsch performed his narcotic experiments only with Cinquantino Mais. For the rest, evacuation in Barley goes on much more rapidly than in Maize, and, as the cell-walls are attacked before the starch, it would be difficult to hold that a tissue which no longer exists as a tissue dissolves its reserves by its own vital activity-a conviction that has already taken possession of Brown and Morris.

In this case also search was made for a pro-enzyme which would become active even in aseptic autolysis at low temperatures. The conclusion was reached that a zymogen does exist, becoming active in the presence of oxygen or of a weak acid-e.g. the endosperm juice gave, directly after trituration, for amylase $3 \mathrm{mg}$. $\mathrm{CuO}$, and after twenty-two days of aseptic maceration $73.2 \mathrm{mg}$. The juice from scutella and embryos gave in the first test $4 \mathrm{mg}$., and in the last $80.3 \mathrm{mg}$. CuO.

One does not wish to say that all the cells of the Barley endosperm must be dead from the beginning of germination. Microscopic researches on vitality showed that if a residue of vitality does exist in the endosperm, we can find it only in the immediately sub-aleuronic tissue, because only there (with difficulty on account of the accumulation of reserve material) can we find a trace of plasmolysis, and because only there can we see, after appropriate staining, vestiges of nuclear substance, though we cannot speak of a well-defined nucleus.

\section{WHEAT.}

In Wheat I was able to get complete emptying of isolated endosperms in free air. In the chloroform atmosphere evacuation could not proceed, and the whole endosperm became very hard, so that in this case chloroform seems to stop both the cytasic and amylasic actions. The behaviour of the individual cells towards plasmolytic agents and stains would demonstrate that they do not renew their vitality during germination. No trace of nuclei could be made out in the endosperm except in the aleurone cells. The solution of reserve material does not prove the vitality of this tissue, because I have been able to show, by the usual methods, that the resting seed contains pro-amylase which becomes active under the influence of oxygen and dilute acids. E.g. in the first amylase test only a trace of $\mathrm{CuO}$ was found, while after twenty days (at $18^{\circ} \mathrm{C}$.) $123.92 \mathrm{mg}$. $\mathrm{CuO}$ were obtained for 5 c.c. endosperm juice. The scutellum and embryo juice gave in the first test only traces of $\mathrm{CuO}$, and in the last $40.26 \mathrm{mg}$. $\mathrm{CuO}$.

In these experiments no account had been taken of the small volume that the scutellum and embryo occupy in the seed, so that juices which had been made with the same amount of water or dilute glycerine were more concentrated in the case of the endosperms than of the scutella and embryo. Therefore one could not exactly estimate the ratio of increasing amylase between the two parts ; inasmuch as, the endosperm extracts being 
more concentrated, the decomposition products would very likely undergo a secondary synthesis, or at any rate the breaking-down process would be stopped.

Concentrated juices were made with the same proportion of water and $\frac{11}{10}$ hydrochloric acid. For a concentration of 2 per cent. at room temperature, the following results were obtained:-

\begin{tabular}{|c|c|c|c|c|}
\hline \multirow{2}{*}{ Date. } & \multicolumn{2}{|c|}{ Endosperm juice. } & \multicolumn{2}{|c|}{ Scutellum and embryo juice. } \\
\hline & Sugar in 5 c.c. & Amylase of 5 c.c. & Sugar in 5 c.c. & Amylase of 5 c.c. \\
\hline $\begin{array}{cr}\text { July } & 3 \\
,, & 7 \\
,, & \text { I } 6\end{array}$ & $\begin{array}{c}\mathrm{CuO} \mathrm{mg.} \\
\begin{array}{l}12 \cdot 5 \\
27 \\
3^{\mathrm{I}}\end{array}\end{array}$ & $\begin{array}{c}\mathrm{CuO} \text { mg. } \\
8 \\
\mathrm{I}_{3} \\
4^{2}\end{array}$ & $\begin{array}{c}\mathrm{CuO} \mathrm{mg} . \\
26 \\
76 \\
80\end{array}$ & $\begin{array}{c}\mathrm{CuO} \text { mg. } \\
\text { I } 2 \\
34 \\
274\end{array}$ \\
\hline
\end{tabular}

As we can see from this table, there is a greater amount and a larger increase of amylase in the juice from scutella and embryos than in the endosperm juice. This would lead one to suppose that the largest quantity of pro-amylase always occurs in the scutellum, and that digestion of reserve materials takes place by its action. Against this we must, however, place the fact that the whole embryo with the scutellum constitutes but a very small part of the seed (about one-eighth, $\frac{1}{8 \cdot 2}$ in weight), while the results of this experiment have been calculated as if the scutellum, \&c., weighed the same as the endosperm.

In reality, then, the amount of pro-enzyme which became active in the endosperm in comparison with that contained in the scutellum and embryo, is shown as follows :-

\begin{tabular}{|c|c|c|c|c|}
\hline \multirow{2}{*}{ Date. } & \multicolumn{2}{|c|}{ Endosperm juice. } & \multicolumn{2}{|c|}{ Scutellum and embryo juice. } \\
\hline & Sugar in 5 c.c. & Amylase of 5 c.c. & Sugar in 5 c.c. & Amylase of 5 c.c. \\
\hline $\begin{array}{cc}\text { July } & 3 \\
,, & 7 \\
, & \text { I }_{4}\end{array}$ & $\begin{array}{l}\mathrm{CuO} \mathrm{mg} . \\
\mathrm{IO} 4 \cdot 50 \\
22 \mathrm{I} \cdot 40 \\
254 \cdot 2\end{array}$ & $\begin{array}{c}\mathrm{CuO} \mathrm{mg} . \\
65.6 \\
\mathrm{I} 06.6 \\
344.4\end{array}$ & $\begin{array}{c}\mathrm{CuO} \text { mg. } \\
26 \\
76 \\
80\end{array}$ & $\begin{array}{c}\mathrm{CuO} \text { mg. } \\
\text { I } 2 \\
34 \\
274\end{array}$ \\
\hline
\end{tabular}

So in the endosperm of the Wheat we find much more pro-enzyme than in the scutellum and embryo, and its action in the presence of free oxygen and dilute acid may itself cause the digestion of the endosperm food material.

Most interesting is the influence of chloroform, which not only inhibits starch hydrolysis in the intact endosperms, but also at first hinders the solution of the cell-walls. This would indicate that the cytase is produced in this endosperm by living cells. However, as the endosperm cells must be considered dead for the most part, for the reasons given above, there is 
no choice but to admit that cytase production occurs only in the aleurone cells, or at most in the directly sub-aleuronic layers.

Wheat was used for a comparative study, by staining methods, of what happens in the amyliferous cells of the seed from the time of the beginning of endosperm formation up to the ripening of the seed.

Results were chiefly obtained by staining properly-fixed material with iodine green, methyl green, malachite green, gentian violet, and by double staining with methyl or malachite green and eosin, gentian violet and eosin, iodine green and orange. With single staining, both in the first stages of endosperm development and in more advanced stages (but always green), a sharp coloration of the nuclei in the starchy cells was obtained. These nuclei were easily distinguished among the starch grains, though the latter were present in great abundance in the later stages and had reached their proper size.

Eosin and orange gave a coloration of the cell protoplasm, while the nuclei absorbed their peculiar stains as iodine green, methyl green, malachite green, gentian violet, \&c., in other stainings, and were clearly distinguishable in the middle of the cells, showing a perfectly normal structure.

As it might be thought that in sections of old endosperms which had been boiled in dilute acid in order to remove the starch, the nucleus would have lost its property of absorbing its peculiar stains on account of the treatment received, young cells with normal nuclei were treated in the same way. In spite of the treatment the nucleus and protoplasm of all the endosperm cells still retained to the full their property of absorbing stains. So it cannot be said that the removal of the reserve starch by dissolving out with dilute acid alters the chemical composition of the nuclear substance, even in ripe and germinating endosperms, sufficiently to hinder staining.

From all these observations it can be inferred that the cells of Wheat endosperms do not regain vitality during germination; but the fact remains that they can empty themselves, even when cut off from the embryo, by means of the activation and functioning of their amylolytic enzymes, and that chloroform has a remarkable inhibiting action on this evacuation.

RYE.

With Rye (Secale cereale) a total evacuation of the endosperm was obtained by the same methods, with a copious diffusion of reducing sugars and other digestion products (albumins) in the surrounding liquid; in the early stages of germination there occurred a complete disintegration of the starchy tissue by separation of the individual cells. Chloroform has no action upon the starch hydrolysis, nor on the dissolution of the walls, nor on the evacuation of the entire endosperm, for, though the seeds became a little 
dark and hard at first, the usual separation of cells occurred, with a plentiful production of reducing sugars, which diffused in the external liquid. From this it may be inferred that the Rye endosperm is dead right up to the aleurone cells. As the hydrolysis of the walls precedes the starch hydrolysis, the latter cannot be ascribed to vital activity of the cells. While in Barley the hemicellulose is first dissolved, and then, almost immediately, the cellulose as well, here the pectic substance of the middle lamella first disappears, and only in a very advanced stage of evacuation, when the starch is almost entirely dissolved, does the hydrolysis and dissolution of the cellulose walls and hemicellulose thickenings begin.

As Puriewitsch does not in any way mention these dissolution processes of the cell-walls, which, moreover, he has also overlooked in Barley and Wheat, the question arose as to whether this Rye might behave differently from other kinds of Rye. I have to thank Professor Pirotta, who was able to procure for me several different kinds of Rye, from various Botanic Gardens, e.g. Secale cereale from the Botanic Gardens, Paris; Secale cereale from the Botanic Garden, Lyons; Secale cereale from Zuttich; Secale cereale aestivum anmuale from the Seed Station, Zurich; Secale cereale perenne from Zurich; Secale cereale from the Botanic Gardens, Marburg; Secale montanum from Paris; Secale montanum from Lyons; Secale cereale from Utrecht, \&c. In all these samples the same phenomena have been observed during endosperm evacuation as those mentioned above for the Roman Rye. Therefore there is no doubt that the Rye on which Puriewitsch worked must have shown the isolation of the endosperm cells.

The following experiments show that the question is really one of a cytolytic enzyme :-

A number of seeds of Rye were soaked for two days in water, and were then pounded and mixed with 25 c.c. water and 25 c.c. glycerine and thymol.

The paste was pressed through a cloth and a portion of the juice was boiled in order to kill the enzymes.

In both these juices boiled sections of Lupin cotyledons were placed, and the whole was set to digest at a temperature of $47^{\circ} \mathrm{C}$.

After twelve days the sections in the unboiled juice showed the hemicellulose layers of the walls decidedly corroded, while they were entirely unaltered in the boiled juice.

In order to ascertain whether this enzyme proceeded from the scutellum or was contained in the endosperm cells themselves, two separate extracts of the endosperms and the rest of the seeds were made in the way above described. The usual boiled sections from the cotyledons of Lupin were put in these extracts and left to digest at $47^{\circ} \mathrm{C}$. After nine days the hemicellulose thickenings were found strongly corroded in both cases.

Sections from Rye seeds were put into the same extracts, and after 
two days wholly lost the amyliferous tissue, nothing remaining of the sections but the aleurone layer and seed envelopes.

Hence it may be concluded that in the Rye endosperm there is a cytase which is not confined to the scutellum. Certainly, it is true that the endosperms had stood for twenty-four hours in water before they were cut from the scutella and embryos, a time which might seem sufficient for exosmosis of enzyme from the scutellum; but it is easy to prove that if Rye endosperms are put to evacuate in the usual manner, from which the scutella and embryos have been cut before the seeds were moistened, the same phenomenon of rapid isolation of the cells may be observed.

Moreover, as direct experiments have proved, the Barley cytase also dissolves the cell-walls of Rye and Wheat very rapidly, while it has no action upon those of Maize. So Rye is not alone in producing an energetic cytase soon after the beginning of germination.

The disintegration of the amyliferous tissue at the beginning of evacuation shows in a convincing way that there is no trace of vitality. Nevertheless, the researches on cytological behaviour were repeated on the Rye. The results did but confirm the above conclusion. In the endosperm cells of Rye no trace of plasmolysis could be seen, and it was impossible by any means to discover a nucleus in the cells filled with starch.

By vital staining the whole amyliferous part of the endosperm stained immediately and completely.

In this case also self-evacuation is caused by a pro-enzyme which becomes active in presence of air or of dilute acid. For instance, an endosperm juice, under conditions of aseptic autolysis, gave in the first amylase test only a trace of $\mathrm{CuO}$, while after twenty-one days $129.93 \mathrm{mg}$. were obtained for 5 c.c. juice; in the corresponding scutellum and embryo juice only vestiges were found in the first amylase test, while in the last $25.6 \mathrm{mg}$. $\mathrm{CuO}$ were obtained.

\section{CONCLUSIONS.}

The starchy endosperm of the investigated grains, Maize, Barley, Wheat, and Rye, can digest itself in the absence of the scutellum and other parts of the embryo, though to a very different degree; hence the diverse results reached by previous authors.

The self-emptying can go on in the absence of any vitality in the amyliferous cells, because the starch hydrolysis is accelerated by a strong amylase which, little by little, arises from a pro-enzyme which exists in the endosperm of the resting seed, and becomes active even though every trace of vitality has been removed from the entire endosperm or seed by mechanical means. Nevertheless, one cannot deny any vitality whatever to the endosperm cells. On the contrary, our researches lead one to admit that vitality, which is certainly possessed by the aleurone cells situated at 
the periphery of the endosperm, is also retained in one or several subaleuronic layers, whence it lessens by degrees till it totally disappears towards the middle of the endosperm, as well as in the part near the scutellum.

This is clearly seen in the Maize, the endosperm of which shows wellmarked, though strangely deformed, nuclei in the cortical, glutinous portion, while they are not to be brought in evidence in the farinaceous central portion which forms the bulk of the endosperm.

In Barley and Wheat, if any trace of vitality is conserved in the amyliferous cells, it must be sought in the immediately sub-aleuronic layers, the larger part of the endosperm being quite dead.

The rapid dismembering of the Rye endosperm at the very beginning shows that it is entirely dead. Its disintegration is due to the influence of a powerful cytase that precedes the amylase action, and dissolves the middle lamellas, while the cellulose layers of the walls are retained for a long time. The cells become isolated, but remain entire with intact starch in the endosperm cavity, so that one can no longer speak of an endosperm tissue.

A similar fact is to be noted in Wheat and Barley, but less marked and at a more advanced period of evacuation; but the phenomenon does not occur in Maize, though a cytase becomes active during the evacuation of this endosperm also.

The discrepancies of preceding authors are very likely due to the fact that they used different species of corn. So that Puriewitsch, Grüss, and Linz, who worked chiefly with Maize, are not wrong in describing its endosperm as partly living, while Brown and his co-workers are right in asserting that the endosperm of Barley is a dead magazine of reserve food.

Between the partly living endosperm of Maize and the totally dead endosperm of Rye, and also between the different parts of a grain of Maize or Wheat, one finds a gradual decrease in vitality. Nevertheless a rapid self-emptying of isolated grass endosperms can take place, for they contain pro-amylase, pro-cytase, \&c., which still exist after the death of the cells, and yield large quantities of active enzymes after soaking in water at ordinary temperatures.

The amount of energy needed for the hydrolysis of starch and hemicellulose is very small, and can originate from the oxidasic, i. e. extra vital, respiration of the sugars formed. Herein one sees a difference between carbohydrate and oil reserves; in the latter only vital activity can supply the energy needed for the complicated formation of sugars, starch, \&c., from the reserve fat. Indeed, I have shown in other papers ('07) that the endosperm of the Castor-oil plant (Ricinus communis) retains its vitality during the whole process of germination or artificial evacuation. 


\section{REFERENCES.}

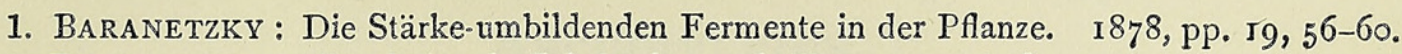

2. BLociszewsky : Landwirtsch. Jahrbücher, vol. iii, p. 145,1876 .

3. Brown and Morris : Journ. Chem. Society, vol. lvii, p. 458 , I89o.

4. Brown and Escombe : Proceed. Roy. Society, London, vol. 1xiii, p. 4I2, I898.

5. Bruschi, Diana : Rendiconti Accademia Lincei (5), vol. xv, ii. Sem., pp. 383-90, 1906.

6.

7. - Rendiconti Accademia Lincei (5), vol. xv, ii. Sem., pp. 563-8, 1906.

8. - Ibidem (5), vol. xvi, i. Sem., pp. 785-9, $190 \%$.

9.

10. Detmer : Botan. Zeitung, i883, p. 60I.

11. Gris : Ann. Sci. nat., Bot. (5), vol. ii, p. 100, 1864.

12. Grüss : Ber. botan. Gesellsch., Bd. xi, p. 286, I893.

13. — : Jahrb. f. wiss. Botan., Bd. xxvi, p. 224, I894.

14. - : Beitr. z. wiss. Botan., Bd. i, p. 295, I895.

15. — : Ber. botan. Gesellsch., Bd. xiii, p. 18, I895.

16. - : Landwirtsch. Jahrbücher, Bd. xxv, p. 43I, 1890.

17. : Jahrb. f. wiss. Bot., Bd. xxx, p. 644, 1897.

18. HaberLandt : Ber. botan. Gesellsch., Bd. viii, p. 40, I 890.

19. : Pflanzenphysiologie, 2nd Edition, 1904, p. 444.

20. Hansteen : Flora, Eng. Bd., I894, p. 4I9.

21. Laurent : Comptes rendus, vol. cxxxi, p. 848, I900.

22. Lintner : Journ. f. prakt. Chemie, Bd. xxxiv, p. 378 , 1886.

23. Lintner and ECKhardT: Ibidem, Bd. xxxviii, p. 91, 1890.

24. Linz: Jahrb. f. wiss. Bot., Bd. xxix, p. $257,1896$.

25. Longo : Annuario d. Istit. Botan. di Roma, vol. ix, p. 189, I9OI-I902.

26. Mosso : Archives ital. de biologie, p. 398 , I 888.

27. Pantanelli : Malpighia, vol. xvii, p. 462, 1902.

28. - Annali di Botanica, vol. iv, p. I, I906.

29. Pfeffer : Unters. a. d. bot. Inst. zu Tübingen, Bd. ii, p. 60 I, 1886.

30. — : Ber. Sächs. Ges. d. Wiss., p. 422 , I893.

31. - Pflanzenphysiologie, 2nd Edition, pp. 518-603, 1897.

32. Pond : Annals of Botany, vol. xx, p. $181,1906$.

33. Puriewitsch : Jahrb. f. wiss. Bot., Bd. xxxi, p. I, I 898.

34. ReED : Annals of Botany, vol. xviii, p. $257,1904$.

35. Reychler : Ber. Chem. Ges., xxii, p. 4I 4, I889.

36. RužıčKa : Archiv f. ges. Physiol., cvii, p. 497, I9०5.

37. SACHS : Botan. Zeitung, p. 3II, I882.

38. SARGant and Robertson : Annals of Botany, xix, p. II $5,1905$.

39. VAN TIEghem : Ann. Sci. nat., Bot. (5), vol. xvii, p. 205, 1873 .

40. $:$ Ann. Sci. nat., Bot. (6), vol. iv, p. 180,1876 .

41. Vinson, Botan. Gazette, vol. xl, pp. 393-407, 1907 .

42. Wortmann, Zeitschr. f. physiol. Chem., vol. vii, p. 472, 1882. 


\section{$2 \mathrm{BHL}$ Biodiversity Heritage Library}

Bruschi, Diana. 1908. "Researches on the vitality and self-digestion of the endosperm of some Graminaceae." Annals of botany 22, 449-463. https://doi.org/10.1093/oxfordjournals.aob.a089182.

View This Item Online: https://www.biodiversitylibrary.org/item/232525

DOI: https://doi.org/10.1093/oxfordjournals.aob.a089182

Permalink: https://www.biodiversitylibrary.org/partpdf/318918

\section{Holding Institution}

Smithsonian Libraries

\section{Sponsored by}

Biodiversity Heritage Library

\section{Copyright \& Reuse}

Copyright Status: Not in copyright. The BHL knows of no copyright restrictions on this item.

This document was created from content at the Biodiversity Heritage Library, the world's largest open access digital library for biodiversity literature and archives. Visit BHL at https://www.biodiversitylibrary.org. 